\title{
Maize diffusion in the Republic of Venice: the case of the Province of Vicenza (sixteenth-eighteenth century)
}

\author{
Giulio Ongaro \\ University of Milan Bicocca, Department of Economics, Management and Statistics
}

The paper has a threefold aim: on the one hand, it wants to contribute to the dating of the first examples of the diffusion of maize in the Republic of Venice, specifically in the Province of Vicenza. In other words, it aims to determine when this cereal appeared for the first time in that area. On the other hand, the chronology and geography of its first appearance can provide some useful hints regarding why and where maize started to be cultivated. Finally, the paper will propose a first and provisional analysis of how this happened. Indeed, as many scholars who dealt with this topic have underlined, maize was not extensively cultivated at the beginning, and its production was not a market-oriented one; this is also true of those areas (such as the Veneto and Friuli regions) where most of the rural population lived on this cereal until the late twelfth century. Moreover, it is still not clear if the use of the so-called sorgo turco for feeding animals preceded its introduction in peasants' gardens in order to integrate the diet of the day labourers and of the small tenants and landowners. The analysis of certain archival sources related to the Province of Vicenza has helped in proposing a hypothesis about the itinerary that maize followed since the last thirty years of the sixteenth century in the area of the province close to the mountains: from the presence of small amounts among the provisions of cereals in households, to its - quite precocious - inclusion in the market mechanisms. 


\section{Maize in the Republic of Venice}

\section{and in the Province of Vicenza: a state of the art}

Since Luigi Messedaglia's studies, who dedicated many pages to maize diffusion from the Americas to Europe, and particularly in the Republic of Venice (Messedaglia 1924; 1927; 2008), many researches have dealt with the chronology and characteristics of the gradual 'conquest' of the countryside by this cereal. Danilo Gasparini (2000; 2002; 2015) in particular analysed maize cultivation in the Venetian area. Sometimes these researches focused, with "rustic erudition" (Gasparini 2002, 12), on the long-standing problem of when and where maize appeared for the first time; however, research into the chronology of its diffusion is not simply a question of who was first. In fact, understanding when and where this happened is crucial in order to establish the why and how.

At the beginning of the sixteenth century, maize reached Spain from the Americas, where it was extensively used, even if in a quite different way compared to its milling and processing into polenta that characterized the countryside of northern Italy. Then it spread with "rapid advancements and prolonged interruptions" (Cazzola 2014, 311) in the Mediterranean area, from the Iberian Peninsula to the Ottoman Empire. Already from the $1620 \mathrm{~s}$ onward, it was cultivated in Andalusia, Catalonia, Galicia and Portugal; afterwards, it rapidly crossed the Pyrenees and spread throughout the southern part of France, where its use in human diet struggled to take hold ${ }^{1}$. The new cereal reached the Italian Peninsula in the mid-sixteenth century; the Republic of Venice was quite probably one of the first areas where maize was accepted not only as an exotic crop, perhaps used as a model for marble friezes, but also for intensive cultivation. This happened in the Province of Rovigo already in the mid-sixteenth century and in the territory of Este (in the Province of Padua) in the $158 \mathrm{os}^{2}$. In conjunction with the famine of the 1590s (Alfani 2010, 232-233; 2011; Clark 1985), maize spread rapidly in the provinces of Treviso and Verona and in the Papal Legations south of the Po River, reaching in the seventeenth century the Province of Belluno, the 
Friuli region, the provinces of Brescia and Bergamo, and finally the rest of the Lombardy region and the Piedmont one ${ }^{3}$.

While sketching the geographical expansion of maize, some elements should be underlined and will be recalled on the following pages: firstly, the introduction of maize initially occurred on marginal fields, usually characterized by a high humidity level that made them unsuitable for the cultivation of wheat ${ }^{4}$. Secondly, it is important to keep in mind that in these fields maize gradually substituted the minor cereals, especially during the famines - we have already referred to the food crisis of the 1590 - because its high yield was a useful instrument in rebalancing the relationship between population and resourcess. Besides these elements, we should not forget that the importance of the yield was accompanied by the 'newness' of maize; indeed, given that it was a previously unknown cereal, it was not included in the farming contracts and in the tithe obligations (Levi 1979, 1095; 1991, 156; Cazzola 2002, 236; 2015, 38, 40, 44). This 'exemption' guaranteed to the peasants the possibility to keep the entire harvest for their families. Finally, Franco Cazzola and Roberto Finzi in particular emphasized the strong relationship between the introduction of maize and the characterization of the agrarian contracts, underlining that the diffusion of this cereal happened initially where the fields were cultivated by day labourers. Indeed, maize became a part of their salary in order to place a greater part of wheat on the market. On the contrary, according to Cazzola with reference to the Emilia Romagna region, "the areas of more ancient cultivation and where there were well-established sharecropping structures [...] experienced generally a greater resistance to the new cereal" (Cazzola 1991, 118120; 2014, 318; 2015, 40, 44-45). Therefore, if in Emilia Romagna the sharecropping areas were characterized by a later diffusion of maize, Giovanni Levi asserts that, at least in Piedmont, also "the areas characterized by the

3 Fassina 1982, 38-50; Coppola 1979; Levi 1979, 1092-1100; Finzi 2009, 28-31; Cazzola 2014, 317; 2015, 39-42; Fornasin 1999; 2000, 11-31; Pezzolo 2011, 101; Rombai and Boncompagni 2002, 188; Doria 2002, 571; Vecchiato 1979, 72; Mocarelli and Vaquero Piñeiro 2018, 26; Sereni 1982, 231; Gasparini 2015b, 138-141.

4 Cazzola 1991, 112-113; 2015, 39, 43; Finzi 2009, 19-20, 28; Cazzola 2014, 314; 2002, 236; Gasparini 2002, 34; Fassina 1982, 32-33, 55; Levi 1991, 160; Montanari 1993, 128 129; Coppola 1979, 38-39.

5 Levi 1991, 156-157, 162; 1979, 1094-1095, 1098; Cazzola 1991, 112, 114-115, 118; 2014, 310-311, 317-319; 2002, 236; 2015, 35, 42-44; Doria 2002, 571; Finzi 2009, 34-35, 43-45; Gasparini 2002, 16, 20-22; Montanari 1993, 163-165; Pezzolo 2011, 101; Fassina 1982, 52-53; Rombai and Boncompagni 2002, 188; Mocarelli and Vaquero Piñeiro 2018, 24; Coppola 1979, 39, 41, 44; Sereni 1982, 231. 
presence of small estates and ones where wheat and grapevines were cultivated experienced a strong resistance" (Levi 1979, 1096). Furthermore, both Cazzola and Finzi have underlined that even if the arrival of maize often coincided with conflicts that involved landowners and peasants, and with situations of relevant changes in the power relationships and in the contracts, they did not happen because of the introduction of the new cereal, even if maize did play a role in these transformations. Finzi, in particular, wrote that "maize cultivation, far from being the cause of changes in the production relationships, seems to be used within processes that started because of other causes" (italic in the original text Finzi 2009, 67; Coppola 1979, 76-77, 105-134).

That being said, when did maize reach the Province of Vicenza? Messedaglia asserted that this happened at the beginning of the seventeenth century (Messedaglia 2008, 174); the subsequent research by Fassina on Lisiera and Mason Vicentino seem to confirm this periodization (Fassina 1982, 45; 1981). Danilo Gasparini recalls Fassina but at the same time refers to a book published by Silvano Fornasa and Sergio Zamperetti on the history of Castelgomberto (a village in the area of the province close to the mountains) (Fornasa 1999, 168-169), where maize was found as early as in 1595, "in inventories and in leases where the landowner reserved the stram$m i$ [i.e. the mulch] of the previous harvest, including the canes of the sorgo rosso and of the sorgo turco [i.e. the maize]". Then, recalling Gasparini, since the beginning of the seventeenth century maize played a prevalent role in shaping the food provisions of the peasants of Vicenza (Gasparini 2002, 27-28). These few lines show that in the Province of Vicenza too, as in other areas, the history of maize is a history of gradually moving the chronology of its diffusion further back, and this paper is no exception.

\section{Before maize: food consumption and characteristics of the Province of Vicenza in the sixteenth century}

In order to understand when, where, how and why maize spread throughout the Province of Vicenza, we should first reconstruct the geographical, economic and demographic context in which this process happened. In the early modern period, the Province of Vicenza was a bordering province of the Republic of Venice, and it was characterized by the presence of many "almost cities" (rural villages with thousands of inhabitants) and by a morphology that was mainly hilly and mountainous. In its northern part, there was the Asiago upland and mountains more than 2,000 metres 
high, while in the central southern part there were the Colli Berici, hills of lower heights. Indeed, according to the data included in the "Provincial Territorial Plan - Environmental Report" prepared in 2009 by the Province of Vicenza (Province of Vicenza, 2009, 7), among the 2,722.2 square $\mathrm{km}$ of the present province (almost corresponding to the early modern one), 1094.25 square $\mathrm{km}$, i.e. $40.2 \%$, are mountainous, 814.25 square $\mathrm{km}(29.9 \%)$ are hilly, and just 813.7 square $\mathrm{km}(29.9 \%)$ are level. Generally speaking, we can therefore say that it was a far from level territory, which had relevant effects on its economic structure. Despite this, from a demographic point of view, the Province of Vicenza was densely populated: according to Fornasin and Zannini (Fornasin and Zannini 1999, 115), in 1548 there were 124,760 inhabitants in the countryside of the province, and 30,948 in the city - so there was a total population of 155,708 . It was a relevant demographic weight (Ongaro 2020): referring to the present borders of the province, it means around 56 inhabitants per square $\mathrm{km}$, including the city, or 46 inhabitants per square $\mathrm{km}$ including only the countryside. Just think that at the end of the eighteenth century the areas that would be the first to industrialize, i.e. England and the Low Countries, had a population density of, respectively, 61 and 51 inhabitants per square $\mathrm{km}$. These figures are even more relevant if we consider the morphology of the territory that implies the concentration of population in the few level areas. Looking at a "food and mouths" (Galletti 1994) register dated 1546 (BCB, AT), which will also be mentioned on the following pages and which records the population of 81 villages of the countryside of Vicenza, we can observe that 24 of them greatly exceeded 1,00o inhabitants and that, among these, seven were characterized by a very relevant population, sometimes nearly reaching 5,000 inhabitants: Brendola (4,728 inhabitants), Montecchio Maggiore $(3,178)$, Thiene $(2,187)$, Arzignano $(4,834)$, Schio $(4,958)$, Lonigo $(2,884)$, Valdagno $(3,070)$. Almost all these villages were located in the area of the province close to the mountains; especially Schio, Arzignano and Valdagno were the fulcrum of the development of manufacture in the countryside of Vicenza in the sixteenth century. Moreover, we must consider that the 1546 survey is incomplete, meaning that other villages (such as Marostica) that were demographically relevant are not included in the register.

As regards the economic structure of the province, especially in the last twenty years, many researchers have outlined the main characteristics of the secondary sector, both in the city (Demo 2001; 2004; 2006) and in the countryside (Vianello 2004; Demo and Vianello 2011); however, the 
agricultural sector was left in the shadow (Ongaro 2017), despite some exceptions (Ferrarese 2008). During the fifteenth and sixteenth century, the city of Vicenza, approximately at the centre of the province, experienced a relevant economic and demographic development (same as many villages in the countryside) thanks to the wool production (first) and to the silk one (second). Furthermore, significant ore bodies in the area close to the mountains had been attracting investments by citizens and Venetian patricians since the end of the fifteenth century (Fontana and Vergani 2003). However, beyond the mining activities, since the sixteenth century - and with an almost uninterrupted growth until the nineteenth century - the area of the province close to the mountains was characterized by a relevant production of wool textiles and raw silk. In the large villages recalled above (Arzignano, Valdagno, Schio), some inhabitants asserted that during their lives they were employed only in the secondary sector, as weavers or wool combers (Vianello 2004). Moreover, even those who were not specialized workers in the textile sector, were involved in the context of a pronounced integrated peasant economy (Panjek, Larsson, and Mocarelli 2017); daily work in the fields was often accompanied by transporting goods for rural merchants, by breeding silkworms, silk reeling and spinning, weaving in peasants' houses, and working in kaolin mines (Demo and Ongaro 2020).

Regarding the agricultural sector, as anticipated there are no specific researches able to clarify the size of the estates, the contracts used, and the cultivation techniques: Andrea Ferrarese wrote, referring to the first phase of expansion of the urban properties in the countryside between the fifteenth century and the beginning of the sixteenth, that the agrarian landscape of the Province of Vicenza was characterized by "a general absence of appoderamento processes, a strong fragmentation of the estates, and by a persistent rigidness of agrarian structures" (Ferrarese 2008, 289). During the sixteenth century, it seems that the situation changed, precisely because of the gradual increase in the urban properties in the countryside, but recent research seems to confirm the absence of large estates with sharecropping contracts and, on the contrary, the potential persistence of small estates or the presence of large estates cultivated by day labourers (Ongaro 2020).

In this context of a mountainous/hilly territory, with a relevant demographic weight, an economic structure based mainly on the secondary sector, especially in the area close to the mountains, and characterized by the absence of relevant sharecropping structures, what was the food of the peasants in the sixteenth century? When is it possible to date the introduc- 


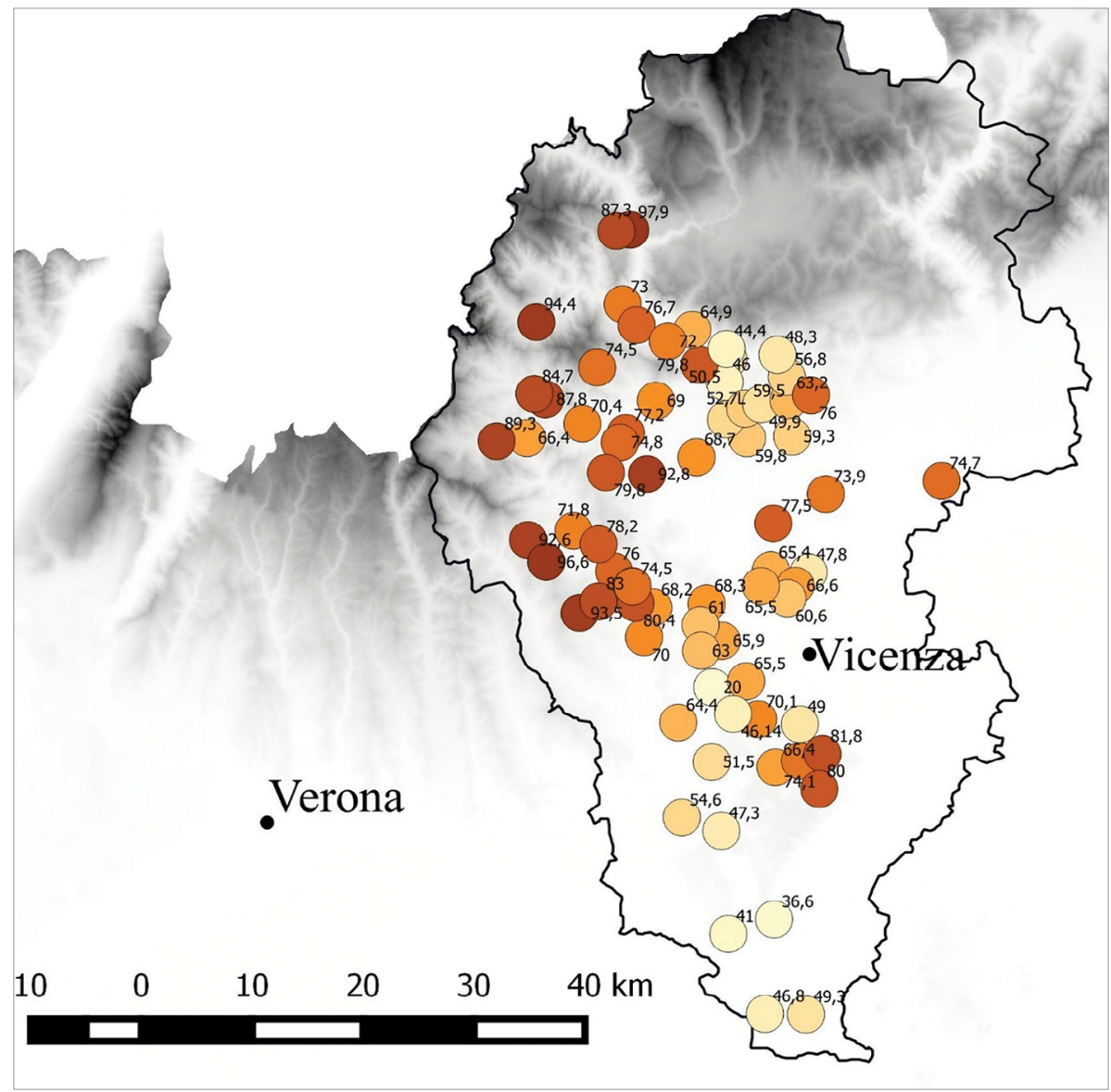

Map i. Percentage of minor cereals in the total amount of cereals (minor and wheat) produced in 1545

Source: BCB

tion of maize? Many sources seem to exclude the presence of the new cereal until the 1570s, or at least it was not reported in the state surveys on agricultural production and was not used as payment in kind for workers in the fields or in factories. Obviously, this does not mean that maize was unknown (even if there is no proof of the contrary), however, if it was cultivated in the gardens of peasants, it did not play a relevant role in terms of human nutrition. Indeed, the analysis of the accounting books of a rural merchant who lived and operated in Schio, Antonio Razzante, dated 15501574, shows that even if almost all the workers who came from a wide geographical area and who were employed in various economic sectors re- 
ceived part of their remuneration in kind and often in minor cereals (millet and rye mostly), maize was completely absent (Demo and Ongaro 2020). The role played by rye, millet, barley, buckwheat, oat and spelt in feeding the peasants, especially in the area of the province close to the mountains, is confirmed by the already mentioned survey of "food and mouths" dated 1546. Figure 1 show the percentage of minor cereals and wheat reported to the Venetian authorities in various villages.

The picture is not surprising and it is certainly not typical only of the Province of Vicenza: in almost all the rural villages, more than 50 percent of food availability was guaranteed by legumes and minor cereals, and often wheat played a marginal role. Certainly, we are in the period before the "boom" of wheat production in the Republic of Venice (in the second half of the century) (Zannini 2010), but it is quite probable that the situation was the same also in the following decades. Furthermore, especially in the hilly and mountainous areas, the consumption of minor cereals and legumes was quite high, between 75 and 97 percent.

\section{Maize in the countryside of Vicenza}

When and where can we place the arrival of maize in the countryside of Vicenza? Fassina was quoted on the previous pages, who asserts that the first example of maize cultivation is dated 1611 and located in the north-eastern part of the province, in the plain between the Tesina and Brenta rivers. Moreover, we referred above to new discoveries that seem to anticipate the arrival of maize - still in the area close to the mountains - at the end of the previous century.

Beyond these examples, new researches help to redefine the chronology and geography of maize diffusion in the Province of Vicenza: Silvano Fornasa wrote that an inventory dated 1570, which referred to goods owned by the Panciera family in a village close to Creazzo, reports "a basket with a small amount of sorgo turco" (Fornasa 2013, 200-201). Furthermore, a survey of agricultural products in private houses drafted by the public officers of San Vito di Leguzzano (a village close to Schio) in 1572 reports "half a staio of sorgo turco" (Snichelotto 2019, 146-148) owned by a local family; that equalled roughly 13 litres, given that one staio of Vicenza amounted to 27,043175 litres (Martini 1883, 823). These amounts are not enormous, but neither are they irrelevant; in those years, maize was probably already a well-known and cultivated product, at least in small quantities, even if we do not know whether it was used for human feeding or for the animals. 
However, in the 1590s, its diffusion was much more widespread; in 1595 for example, some staia of maize (i.e. dozens of litres) were reported not in peasant houses, but in the estates of the noble families Trissino and Piovene in Castelgomberto - close to Valdagno, in the Agno Valley (Fornasa 2002). Moreover, another element that suggests that maize was fully included in the local agricultural structure already in the 1590 os is its mention in contracts - such as the strammi in Castelgomberto referred to above - and especially the fact that it was no longer excluded from the tithes. On the contrary, as anticipated, this was an element that characterized the first steps of its diffusion. In 1597 for example, Girolamo and Asdrubale Trissino, who owned some estates in the Agno Valley, between Arzignano and Trissino, shared the tithes of the sorgo turco cultivated in Castelgomberto (Fornasa 2002). Moreover, in 1599, Natale Faggion signed the contract for the collection of the "sorgo turco tithe"; according to Fornasa, in the same year the production of the new cereal in Trissino was around 500 staia (around 10,000 kg) (Fornasa 2003, 126).

Therefore, in the mid-159os, maize - at least in the area close to the mountains - spread out from the peasant gardens and was cultivated on the estates of the noble families of Vicenza (and included in the tithes); however, an archival source leads us to anticipate the diffusion of the new cereal at the end of the previous decade. Indeed, the historical archives of the Municipality of San Vito di Leguzzano include a relevant price series of agricultural products, dated 1587-1708 (ASCSVL). In the sixteenth century, San Vito was a village with around 1,0oo inhabitants and part of the administrative district (Vicariato) of Schio in the area of the Province of Vicenza close to the mountains (Snichelotto 2019; Ranzolin, Snichelotto, and Zuccollo 2007; De Tomasi 1993). Prices are recorded at the end of the books that collected the fines imposed by the marighi and saltari (rural police officers) because of damages to public and private properties (Ongaro and Savio 2019; Ongaro 2016; Snichelotto 2005). This means that they were probably the prices used to fix the refunds due by the transgressors to the owners of the fields and woods that had been damaged; therefore, they were not real market prices, but were certainly closely related to them, given that the price of every agricultural product was established on the basis of the market price recorded for that product every year. The price series of San Vito di Leguzzano is particularly interesting because already in 1587 the price of maize (sorgo turco) was recorded almost uninterruptedly, together with the prices of wheat, sorghum, buckwheat, millet, rye, panico, vetch 
and other legumes, chestnuts and various fruits; it is interesting, even if not for the aims of this paper, that the prices of mulberry leaves, which were widely used for the rearing of the silkworms, were also included.

The fact that, as we will see on the following pages, the prices of maize were strongly related to those of other cereals and particularly to those of wheat, suggests that already at the end of the 1580 s, so before the famine of the gos, the sorgo turco was widespread and used especially for human consumption, together with other cereals.

Before a more specific analysis of the transition of maize from being a 'garden cereal' to its complete inclusion in the market dynamics, it is interesting to propose a hypothesis about the geography and chronology of this process. First, it is clear that, at least according to the archival sources which have come to light so far, maize appeared for the first time in the villages in the north-western part of the Province of Vicenza: it was the most densely populated area of the province, where relevant villages, such as Arzignano, Schio or Valdagno, were located. Therefore, it was an area with an important demographic pressure in terms of the equilibrium between population and food resources, given also that the area close to the mountains and its valleys (Chiampo, Leogra and Agno) were certainly not the most suitable for the cultivation of wheat. As shown in Figure 1, in this area consumption of minor cereals assured the survival of the population: quoting Fornasa, who refers to the Agno Valley (where Valdagno, Trissino and Castelgomberto were located), in that valley "peasants preferred to cultivate the minor cereals that guaranteed a more certain yield"; during the early modern period "the yellow maize polenta and the grey one made with buckwheat stood out in the peasant diet in the Agno Valley, with a difference due to the elevation: in the villages on the valley floor the first one prevailed, while the second one characterized the villages in the hills and in the high valley" (Fornasa 2012, 38-39). The case of San Vito in the Leogra Valley is another clear example of this: in this village, according to the 1546 survey, $92 \%$ of the harvest consisted of minor cereals; an absolutely preponderant percentage. Therefore, it is not surprising that that was exactly where maize found fertile ground for a rapid diffusion, also for human nourishment. Indeed, not only was the morphology of the area not suitable for the extensive cultivation of wheat - contrary to the southern part of the province - but the economic structure also developed according to this characterization: as anticipated, between the fifteenth and sixteenth century a flourishing textile industry was strengthened in these very villages and 
valleys. At the moment, there is a lack of specific research on this topic, but we can hypothesize that this element also affected the diffusion of maize. Similarly, specific research on agrarian contracts and on the agricultural production could provide useful information on the cultivation techniques and varieties of products.

Moreover, if it is true that in this area, too, the general cultivation of maize and especially the moment in which it substituted the other minor cereals in the harvests and in the peasant diet - as we have observed, this often depended on the elevation of the villages - happened during the famine of the 1590s, and then completely between the seventeenth and eighteenth century, it is also true that a previous situation of food scarcity could have facilitated its inclusion in the rural alimentary regimen. In this sense, especially the 1569-1572 famine that affected central and northern Italy has a chronology that is entirely compatible with the examples referred to in the previous lines (Alfani, Mocarelli and Strangio 2015, 4, 7-8, 10, 26; Alfani and O' Grada 2017, 8-9; Alfani, Mocarelli and Strangio 2017, 29-35).

\section{Maize in the Province of Vicenza:}

self-consumption or market? A hypothesis.

Before concluding this short and preliminary analysis of the diffusion of maize in the Province of Vicenza in the early modern period, it is interesting, referring to the examples quoted above, to propose a hypothesis on the use of the new cereal and especially on its connection with the market dynamics. This topic is widely recalled in the historiography on maize: Marco Doria wrote that, within a process that continued to intensify until the eighteenth century, "a dualistic cereal growing [...] took place: the wheat one, market-oriented; the maize one, the key element of subsistence and a poor economy" (Doria 2002, 572; Levi 1991, 161). Montanari recalls this bipartition that seems to link maize consumption to poverty and wheat to richness, given its high price; however, this does not exclude the inclusion of maize in market dynamics, to which especially the day labourers and the salaried workers resorted (Montanari 1993, 167). Furthermore, the importance of maize in the organization of both the rural and the urban market has been extensively demonstrated thanks to the research on the Lombardy and Umbria regions conducted by Luca Mocarelli and Manuel Vaquero Piñeiro (Mocarelli and Vaquero Piñeiro 2018, 25, 42-43), however, their focus is on the eighteenth century; scholars who analysed the first steps of maize diffusion stressed the fact that the new cereal appeared ini- 
tially in peasant gardens, because it 'eluded' the tithes and the obligations to transport part of the cereals to the cities, first for use in animal breeding, and later for self-consumption (Gasparini 2002, 17; Alfani 2010, 232233; Cazzola 1991, 112-113). The examples referring to Creazzo (1570) and San Vito (1572) can be read in this sense, even if the sources do not refer explicitly to the real use of the cereal. The cultivation of maize on aristocratic estates, the increase in the amounts harvested, and the inclusion of the cereal in agrarian contracts and in the tithes in the 1590 os suggest its precocious diffusion and, almost certainly, its inclusion in the local and supralocal commercial channels. The research by Mocarelli and Vaquero Piñeiro on the grain market in Lombard and Umbrian cities in the eighteenth century, among others, confirms the validity of the price trend as an indicator of the market integration and of the role played in it by maize (Mocarelli and Vaquero Piñeiro 2018, 21, 25, 42-43). Briefly, a high correlation of price series suggests the development of a commercial space, thanks to the cereals that show common trends. For this reason, the connection of the price trends of various cereals has been interpreted as a valid indicator of their level of commercialization (Mocarelli and Vaquero Piñeiro 2018, 21, 42; Gasparini 2002, 13); therefore, if this level is high, their consumption would be released from mere self-consumption (that could exist regardless) and they were certainly included in broader commercial circuits. Giovanni Levi, too, asserts that maize "reached the markets later compared to when it became a relevant crop, and was even more slowly included in the surveys of market

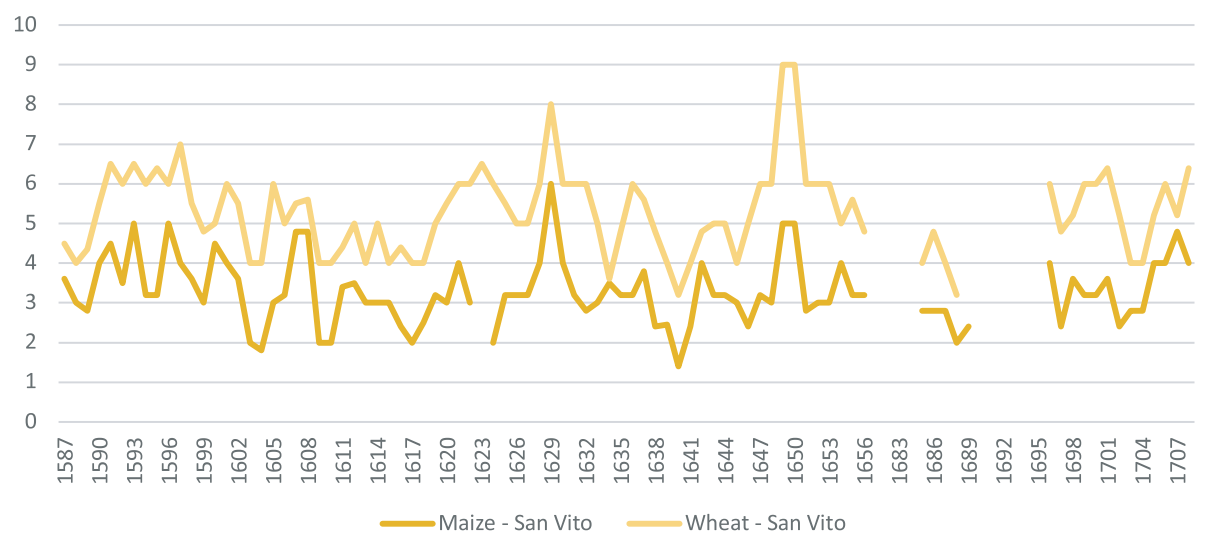

Graph I. Wheat and maize prices in San Vito, 1587-1708 (decimalized Venetian lire per staio) Source: ASCSv 
prices". This strengthens the importance of the prices (and of their control) in defining a product's level of commercialization (Levi 1991, 156).

Graph 1 shows the price trends of wheat and maize in San Vito between 1587 and 1708; the trends are fundamentally synchronized, and their correlation index is 0.67 . If we look at the correlation between the two series in shorter periods, the picture is even more interesting (Table 1).

\section{Table I. Correlation index of maize and wheat prices in San Vito (1587-1689)}

\begin{tabular}{ccc} 
Period & Number of years & Correlation index \\
\hline $1587-1601$ & 15 & 0.52 \\
\hline $1602-1616$ & 15 & 0.73 \\
\hline $1617-1631$ & 15 & 0.79 \\
\hline $1632-1646$ & 15 & 0.46 \\
\hline $1647-1656$ & 10 & 0.80 \\
\hline $1685-1689$ & 5 & 0.82 \\
\hline
\end{tabular}

\section{Source: ASCSVL}

Table 1 shows - even if it was not possible to select fifteen-year samples especially for the last period, which may have produced a partial distortion of the results - that during a century there was a clear increase in the correlation, and therefore in the degree of integration of the maize and wheat markets. Moreover, it shows also a disintegration of the cereal market after the seventeenth century plague; however, for this paper it is important to underline that in the fifteen-year period of 1587-1601 the correlation index is 0.52 . Certainly, this value is lower compared to the ones in the seventeenth century, but it suggests a relevant correlation between the two price series; therefore, a probable influence of the wheat prices on the trend of the maize ones and, finally, the resulting precocious introduction of this cereal in the market dynamics.

The presence of maize in the cereal market at the end of the sixteenth century is certified, but how ample was this market? In other words, was its commerce limited to San Vito or, on the contrary, was there already in that period at least a regional market? In this case the analysis of price series again provides useful information, as Graph 2 shows. 


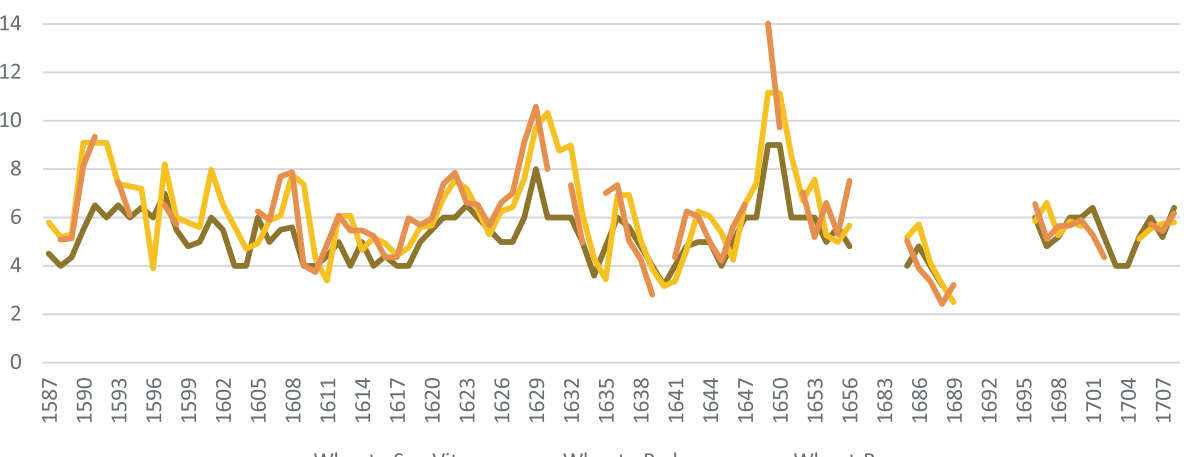

Graph 2. Wheat prices in Padua (decimalized Venetian lire per staio of Padua), San Vito and Bassano (decimalized Venetian lire per staio of Vicenza) ${ }^{6}$

In this case too, the coefficients of correlation between the series are quite high: 0.77 between Padua and San Vito; 0.79 between San Vito and Bassano. Moreover, the comparison of the maize prices in San Vito and the wheat prices in Padua and Bassano produces coefficients of correlation of, respectively, 0.5 and 0.72 ; therefore, the correlation is quite higher between San Vito and Bassano.

In conclusion, not only did the maize in San Vito start its process of inclusion in the cereal market in the $158 \mathrm{os}$, but the market itself went beyond the borders of the Province of Vicenza, and it was strongly related to the price trends in the bordering markets. Furthermore, as anticipated, the mechanism of the tithes itself testifies to the relevance of the new cereal already at the end of the sixteenth century; however, beyond this, it would be relevant to understand, as Gasparini suggests, "why and when [...] it was included in the rentals as were the other cereals, and which were the contract terms" (Gasparini 2002, 13), because these elements could contribute to understanding its emergence.

\section{Conclusions}

The picture sketched on the previous pages testifies, on the one hand, to the precocious inclusion and diffusion of maize in the villages of the area

6 About sources, prices of wheat in San Vito are in ASCSv, for Bassano see Lombardini 1963, while for Padua data has been collected by Professor Luciano Pezzolo. I want to thank him for shared them with me. 
of the Province of Vicenza close to the mountains. The first examples of the presence of the new cereal are dated as early as 1570 ; by the 1580 os and 90 s maize seems to have been included in the market mechanisms - as proved by the correlation of prices with other cereals and the prices of wheat in various markets - in the tithes, and in the agrarian contracts. It spread in an area with a high demographic pressure that affected the relationship between population and food resources, especially taking into account the morphology of the area that was less suitable for the cultivation of wheat. As it happened in other areas, in Veneto and specifically in the Province of Vicenza too, maize spread where there was already a relevant consumption of minor cereals (Gasparini 2002, 13; Pezzolo 2011, 101; Fassina 1982, 52-53, $55)$, which it substituted gradually as the main foodstuff in peasant diet with the resulting problems of pellagra and malnourishment ${ }^{7}$. However, it is difficult to link the diffusion of maize with the structure of the agricultural sector: indeed, on the one hand, according to Cazzola the new cereal spread firstly where there were large estates farmed with cattlemen and schiavenza contracts (work in exchange for money and in-kind payments), and later in the areas with the prevalence of sharecropping (Cazzola 1991, 118-120; 2014, 318; Finzi 2009, 66-72). However, this does not explain why in the Province of Bergamo for example, "where sharecropping lasted for a long time, it supported [...] a wider expansion of maize", and there the new cereal was well received quite early, roughly since the second decade of the seventeenth century (Coppola 1979, 17-18, 107-109). This is maybe due to the fact, as Cazzola himself underlines, that not all the sharecropping relationships were the same; what was valid for the provinces of Bologna and Ferrara and their "rich" sharecroppers, could not apply to the poorer families of sharecroppers that had a lower bargaining power with the landowners. Indeed, probably the definition of the contracts, the choices of the landowners or of the tenants on what should be sown and on the subdivision of production affected the diffusion of maize more than the sharecropping structure itself. There is no specific research on the agrarian structure of the Province of Vicenza, therefore it is not possible to confirm or reject these interpretations; however, it seems that in the area of the province close to the mountains, which was characterized by strong manufacturing professions, the sharecropping of ample estates was absent; but we do not know if there was a prevalence of sharecropping of small properties,

7 Coppola 1979, 114-134; Doria 2002, 572-573, Gasparini 2002, 103-110; Finzi 2009, 81134; Cazzola 1991, 121-122; 2015, 35. 
if peasants owned or rented small plots, or if there were large estates cultivated by day labourers or salaried workers (Ongaro 2020).

Instead, we can confirm that maize tended to spread first in marginal fields (Fassina 1982, 55) and in areas located in the hills or close to the mountains (Gasparini 2002, 34); indeed the villages where the first examples of its cultivation have been found were situated close to the Prealps, often in valleys that were not suitable for the cultivation of wheat. However, in the mountains the cultivation of maize was more difficult. There, the peasants consumed other crops, e.g. chestnuts in the Piedmont mountains (Levi 1991, 160), or buckwheat in the Agno Valley. Similarly, we can confirm that the difficulties in maintaining the delicate equilibrium between population and resources was exactly what facilitated the diffusion of maize and its use for human consumption (Levi 1991, 162; Cazzola 2002, 236; 2014, 317-319); indeed, not only are the case studies in the Province of Vicenza characterized by a relevant population density, but the chronologies of the introduction and of the spread of maize cultivation are linked to two situations of relevant food scarcity: the famine of 1569-1572 and the far more severe one in the 1590 .

\section{Bibliography}

Archival sources

ASCSVL: Archivio Storico Comunale di San Vito di Leguzzano, b. 4/I to 4/VI. BCB, AT: Biblioteca Civica Bertoliana, Archivio Torre, b. 302.

\section{Literature}

Provincia di Vicenza. 2009. Piano Territoriale di Coordinamento Provinciale Rapporto Ambientale.

Alfani, G. 2010. Il Grand Tour dei Cavalieri dell'Apocalisse. L'Italia del «lungo Cinquecento» (1494-1629). Venezia: Marsilio (English edition: Calamities and the Economy in Renaissance Italy. The Grand Tour of the Horsemen of the Apocalypse. London-New York: Palgrave Macmillan, 2013).

Alfani, G. 2011. 'The Famine of the 1590s in Northern Italy. An Analysis of the Greatest "System Shock” of Sixteenth Century'. Histoire \& mesure, XXVI (1): $17-50$.

Alfani, G., L. Mocarelli, and D. Strangio. 2015. 'Italian Famines: An overview (ca.1250-1810)'. Dondena Working Papers 84, December. 
Alfani, G., L. Mocarelli, and D. Strangio. 2017. 'Italy'. In Famine in European History, edited by G. Alfani and C. O’ Grada, 25-47. Cambridge: Cambridge University Press.

Alfani, G. and C. O' Grada. 2017. 'Famines in Europe: An Overview'. In Famine in European History, edited by G. Alfani and C. O’ Grada, 1-24. Cambridge: Cambridge University Press.

Cazzola, F. 1991. 'L'introduzione del mais in Italia e la sua utilizzazione alimentare'. PACT. Journal of the European Study Group on Physical, Chemical, Mathematical and Biological Techniques Applied to Archeology 26: 109-127.

Cazzola, F. 2002. 'Colture, lavori, tecniche, rendimenti'. In Storia dell'Agricoltura Italiana. II. Il Medioevo e l'Età Moderna, edited by G. Pinto, C. Poni, and U. Tucci, 223-253. Firenze: Edizioni Polistampa.

Cazzola, F. 2014. Contadini e agricoltura in Europa nella prima età moderna (1450-1650). Bologna: Clueb.

Cazzola, F. 2015. 'Il mais. Un nuovo cereale per la fame europea'. In Il mais nella storia agricola italiana iniziando dal Polesine, edited by D. Gasparini, 35-46. Rovigo: Minelliana.

Clark, P. (ed.) 1985. The European Crisis of the 1590s: Essays in Comparative History. Boston: George Allen and Unwin.

Coppola, G. 1979. Il mais nell'economia agricola lombarda. Dal secolo XVII all'unità. Bologna: Il Mulino.

De Tomasi, V. 1993. 'Una comunità rurale in età moderna: S. Vito di Leguzzano tra '500 e '600'. Archivio Veneto V (175): 27-60.

Demo, E. 2001. L'anima della città. L'industria tessile a Verona e Vicenza (140o1550). Milano: Unicopli.

Demo, E. 2004. 'Le manifatture tra medioevo ed età moderna'. In L'industria vicentina dal Medioevo a oggi, edited by G. L. Fontana, 21-126. Padova: CLUEP.

Demo, E. 2006. 'Wool and Silk. The Textile Urban Industry of the Venetian Mainland (XV-XVII centuries)'. In At the Centre of the Old World. Trade and Manufacturing in Venice and the Venetian Mainland (140o180o), edited by P. Lanaro, 217-243. Toronto: Centre for Reformation and Renaissance Studies.

Demo, E., and G. Ongaro. 2020. 'Rural merchants in the Early Modern Republic of Venice'. Forthcoming.

Demo, E., and F. Vianello. 2011. 'Manifatture e commerci nella Terraferma veneta in Età moderna'. Archivio Veneto VI (1): 27-50. 
Doria, M. 2002. 'Le colture del Nuovo Mondo'. In Storia dell'Agricoltura Italiana. II. Il Medioevo e l'Età Moderna, edited by G. Pinto, C. Poni, and U. Tucci, 569-578. Firenze: Edizioni Polistampa.

Fassina, M. 1981. 'Elementi ed aspetti della presenza del mais nel Vicentino, con particolare riferimento a Lisiera e alla zona attraversata dal fiume Tesina' In Lisiera: immagini, documenti e problemi per la storia e cultura di una Comunità veneta, edited by C. Povolo, 309-325. Vicenza: Parrocchia di Lisiera.

Fassina, M. 1982. 'L'introduzione della coltura del mais nelle campagne venete'. Società e Storia 15: 31-59.

Ferrarese, A. 2008. 'Il territorio vicentino nel Cinquecento: contesti agrari e assetti protoindustriali'. In Palladio 1508-20o8. Il simposio del Cinquecentenario, edited by F. Barbieri, 288-291. Venezia: Marsilio.

Finzi, R. 2009. "Sazia assai ma dà poco fiato". Il mais nell'economia e nella vita rurale italiane. Secoli XVI-XX. Bologna: CLUEB.

Fontana, G. L., and R. Vergani. 2003. 'Dall'argento al caolino: l'industria mineraria vicentina dal XV al XX secolo'. In Atti della Giornata di Studio: l'argento e le "terre bianche" del Tretto e della Val Leogra. Giacimento, miniere e vicende di una millenaria industria estrattiva, edited by P. Frizzo, 77-94. Schio: Menin.

Fornasa, S. 1999. 'L'uomo, la terra e l'anima. Storia di famiglie, vita economica e dimensione religiosa a Castelgomberto in età moderna'. In Castelgomberto. Storia di una comunità rurale dal medioevo all'Ottocento, edited by S. Fornasa and S. Zamperetti, 148-191. Castelgomberto: Comune di Castelgomberto.

Fornasa, S. 2002. 'L'agricoltura della Valle dell'Agno in età moderna'. In Storia della Valle dell'Agno. L'ambiente, gli uomini, l'economia, edited by G. A. Cisotto, 517-533. Valdagno: Comune di Valdagno.

Fornasa, S. 2003. 'L'età moderna'. In Storia di Trissino. Dai primi insediamenti all'età contemporanea, edited by G. Trivelli, 95-181. Padova: Biblos.

Fornasa, S. 2012. 'Otto secoli di storia e devozione’. In Santa Maria di Panisacco. Otto secoli di storia e devozione, edited by L. De Vicari and S. Fornasa, 1196. Cornedo Vicentino: Comune di Cornedo Vicentino.

Fornasa, S. 2013. 'Creazzo in età moderna: economia, società, politica'. In Storia di Creazzo dal Mille al 1818, edited by M. Knapton, 161-306. Cornedo Vicentino: Mediafactory. 
Fornasin, A. 1999. 'Diffusione del mais e alimentazione nelle campagne friulane del Seicento'. In Vivere in Friuli. Saggi di demografia storica, edited by M. Breschi, 21-42. Udine: Forum.

Fornasin, A. 2000. La Patria del Friuli in età moderna. Saggi di storia economica. Udine: Forum.

Fornasin, A., and A. Zannini. 1999. 'Crisi e ricostruzione demografica nel Seicento veneto'. In La popolazione italiana nel Seicento, edited by M. N. Amorim, 103-122. Bologna: CLUEB.

Galletti, G. 1994. Bocche e biade. Popolazione e famiglie nelle campagne trevigiane dei secoli XV e XVI. Treviso: Edizioni Canova.

Gasparini, D. 200o. 'Una provvida gloria regionale: il mais nel Veneto. Dal formentone all'Insubria 521, dal Marano vicentino a Lolita'. Venetica III (3): $1-47$.

Gasparini, D. 2002. Polenta e formenton. Il mais nelle campagne venete tra XVI e XX secolo. Sommacampagna: Cierre.

Gasparini, D. 2003. 'Evoluzione storica dei cereali nel Veneto'. In Cereali del Veneto. Le varietà di frumento tenero e mais della tradizione veneta, edited by M. Bressan, L. Magliaretta, and S. Pino, 21-73. Vicenza: Regione del Veneto.

Gasparini, D. (ed.). 2015. Il mais nella storia agricola italiana iniziando dal Polesine. Rovigo: Minelliana.

Gasparini, D. 2015b. 'Dai pestarei...ai cornflakes. Il mais nel sistema alimentare veneto dal XVI al XIX Secolo'. In Il mais nella storia agricola italiana iniziando dal Polesine, edited by D. Gasparini, 137-174. Rovigo: Minelliana.

Levi, G. 1979. 'Innovazione tecnica e resistenza contadina: il mais nel Piemonte del '600’. Quaderni Storici 42: 1092-1100.

Levi, G. 1991. 'L'energia disponibile'. In Storia dell'economia italiana, II L'età moderna verso la crisi, edited by R. Romano, 141-168. Torino: Einaudi.

Lombardini, G. 1963. Pane e denaro a Bassano tra il 1501 e il 1799. Venezia: Neri Pozza.

Martini, A. 1883. Manuale di metrologia, ossia misure, pesi e monete in uso attualmente e anticamente presso tutti i popoli. Torino: Loescher.

Messedaglia, L. 1924. Notizie storiche sul mais: una gloria veneta: saggio di storia agraria. Venezia: Officine grafiche C. Ferrari.

Messedaglia, L. 1927. Il mais e la vita rurale italiana. Saggio di storia agraria. Piacenza: Federazione Italiana dei Consorzi Agrari. 
Messedaglia, L. 2008. La gloria del mais e altri scritti sull'alimentazione veneta. Costabissara: Angelo Colla Editore.

Mocarelli, L., and M. Vaquero Piñeiro. 2018. 'El maíz en Italia, siglos XVI-XIX: precios, mercados y haciendas agrícolas (dos casos de estudio: Lombardía y Umbría)'. Obradoiro de Historia Moderna 27: 21-48.

Montanari, M. 1993. La fame e l'abbondanza. Storia dell'alimentazione in Europa. Roma-Bari: Laterza.

Ongaro, G. 2016. 'Il problema della contabilità delle proprietà collettive nella Repubblica di Venezia tra il XVI e XVII secolo: alcuni esempi nel contado vicentino’. Studi storici Luigi Simeoni 46: 43-54.

Ongaro, G. 2017. 'Storia economica delle campagne venete in età moderna: nuove prospettive di ricerca'. Archivio Veneto VI (14): 67-87.

Ongaro, G. 2020. 'Famiglia, agricoltura e manifattura nel Vicentino di età moderna'. In La famiglia tra mutamenti demografici e sociali. Atti del Convegno SiDeS (Bologna, 24-26 ottobre 2018), edited by A. Samoggia and F. Scalone. Forthcoming.

Ongaro, G., and A. Savio. 2019. 'La mariganza e il controllo del territorio'. In San Vito e Leguzzano. Due paesi diventati comunità. Dal Medioevo agli anni Duemila, edited by P. Snichelotto, 271-293. Cornedo: Mediafactory.

Panjek, A., J. Larsson, and L. Mocarelli (eds.). 2017. Integrated Peasant Economy in a Comparative Perspective. Alps, Scandinavia and Beyond. Koper: University of Primorska Press.

Pezzolo, L. 2011. 'La storia agraria veneta: risultati, ipotesi e prospettive'. Archivio Veneto VI (1): 79-110.

Ranzolin, A., P. Snichelotto, and M. Zuccollo(eds.). 2007. Statuemo et ordinemo. Statuti del comune di San Vito di Leguzzano. Schio: Grafiche Marcolin.

Rombai, L., and A. Boncompagni. 2002. 'Popolazione, popolamento, sistemi colturali, spazi coltivati, aree boschive ed incolte'. In Storia dell'Agricoltura Italiana. II. Il Medioevo e l'Età Moderna, edited by G. Pinto, C. Poni, and U. Tucci, 171-221. Firenze: Edizioni Polistampa.

Sereni, E. 1982. Storia del paesaggio agrario italiano. Roma-Bari: Laterza (or. ed. 1961).

Slicher Van Bath, B. H. 1972. Storia agraria dell'Europa occidentale (500-1850). Torino: Einaudi.

Snichelotto, P. 2005. 'Furti e danni campestri nella San Vito del Cinquecento e del Seicento'. Sentieri Culturali 5: 95-114. 
Snichelotto, P. 2019. 'San Vito e Leguzzano, comunità divise'. In San Vito e Leguzzano. Due paesi diventati comunità. Dal Medioevo agli anni Duemila, edited by P. Snichelotto, 21-214. Cornedo: Mediafactory.

Vecchiato, F. 1979. Pane e politica annonaria in Terraferma veneta tra secolo XV e secolo XVIII (il caso di Verona). Verona: Zendrini.

Vianello, F. 2004. Seta fine e panni grossi. Manifatture e commerci nel Vicentino, 1570-1700. Milano: Franco Angeli.

Zannini, A. 2010. 'Sempre più agricola, sempre più regionale. L'economia della Repubblica di Venezia da Agnadello al Lombardo Veneto (1509-1817)'. Ateneo Veneto III, 9 (1):137-171. 